\title{
Phytochemical screening and study of comparative antibacterial activity of aqueous and alcoholic extracts of the leaves and barks of Terminalia catappa on multiresistant strains.
}

\author{
Rubens Dinzedi Mbengui1, 2, Nathalie K. Guessennd 2, Gervais M. M'boh³, Julien K. Golly'; \\ Constantin 0 Okou1; Jean D. Nguessan'; Mireille Dosso² ; Joseph A Djaman 1,3 \\ ${ }^{1}$ Biochemical Pharmcodynamie Laboratory, University Felix Houphouet Boigny 22 BP 582 Abidjan 22, Côte d'Ivoire, \\ 2 Department of Bacteriology and Virology - Institute Pasteur of Côte d'Ivoire, 01 BP 490 Abidjan Côte d'Ivoire \\ 3 Department of clinical and fundamental Biochemistry - Institute Pasteur of Côte d'Ivoire, 01 BP 490 Abidjan, Côte \\ d'Ivoire \\ Corresponding author: rdinzedi@yahoo.fr ; Tel. №. +225 05621524/ 48306965
}

Original submitted in on 13 $3^{\text {th }}$ April 2013 Published online at www.m.elewa.org on 30th June 2013.

https://dx.doi.org/10.4314/jab.v66i0.95000

\begin{abstract}
Objectives: In this study, methanol, ethanol and aqueous extracts of Terminalia catappa L. leaves and barks were compared for antibacterial activity against clinical (sensitive and multidrug-resistant) and ATCC strains of Escherichia coli, Klebsiella pneumoniae and Staphylococcus aureus (MRSA).

Methodology and Results: The confirmation of the Enterobacteriaceae Extended-Spectrum- $\beta$ - Lactamases (ESBL) producing strains was done by the double-disc synergy tests, the MRSA by disk diffusion method (cefoxitin $30 \mu \mathrm{g}$ ) according to the methods of CA-SFM, 2009. The agar dilution and broth dilution method was used for the determination of the antimicrobial parameters (MIC and MBC) on these sensitive, ESBL producing and MRSA strains. The bark extracts generally showed better activity compared to leaves extracts; but methanolic extracts of barks were the most active of all the extracts, exhibiting a broadspectrum activity. However, Staphylococcus aureus were sensitive compared to Escherichia coli and Klebsiella pneumoniae. Antibacterial activity showed value ranged from $0.52 \pm 0.13$ to $4.16 \pm 1.04 \mathrm{mg} / \mathrm{ml}$ (MIC) and 1.56 to $10.42 \pm 2.08 \mathrm{mg} / \mathrm{ml}(\mathrm{MBC})$. Phytochemical screening showed the presence of Flavonoids, Alkaloid, Steroid, Terpenoids, Gallic Tannins, Saponins and with the exception of the aqueous extract for Coumarins.

Conclusions: The results obtained suggest that methanolic extracts of $T$. catappa barks can be used in treating bacterial diseases.
\end{abstract}

Key words: Phytochemical Screening; Comparative Antibacterial activity; Terminalia catappa; multiresistant strains.

\section{INTRODUCTION}

Progress of antibiotic therapy seemed to have solved almost all common problems in infectious diseases. Subsequently, the dramatic emergence of resistance in bacteria previously susceptible to multidrugs becomes a serious problem (Ndiaye,
2005). For over 20 years, there has been a steady increase in antibiotic resistance in hospitals and the community. This is a real public health problem and thus puts into question the validity of the antibiotics currently available. (WHO, 2002a, Stahl, 
2006). In Côte d'Ivoire and worldwide, Staphylococcus aureus resistant to methicillin (MRSA) and Enterobacteriaceae ExtendedSpectrum- $\beta$ - Lactamases (ESBL) producing Escherichia coli and Klebsiella pneumoniae are among the most common resistant organisms (Rong-Dih et al., 2005; Sorlózano et al., 2007; Guessennd et al., 2008; Belmonte et al., 2010; Gandolfi et al., 2011; Kacou-N'Douba et al., 2011). The lack of new molecules, as well as the diversity of resistance mechanisms require the development of new therapeutic agents in the fight against this scourge (Adebayo-Tayo and Adegoke, 2008; Nyenje et al., 2011). Medicinal plants are an important source of new drugs adapted to the financial resources and the socio-cultural populations and especially since, they have fewer side effects (Maghrani et al., 2005; Doughari et al., 2007). According to WHO estimates (2002 b),

\section{MATERIALS AND METHODS}

Plant material: The plant material consisted of bark and leaves of Terminalia catappa collected on the campus of the University of Cocody between June-July 2009. They were authenticated at the National Centre of Floristic the University of Cocody. The leaves and bark of Terminalia catappa were washed, cut and dried in sunlight at room temperature $\left(25^{\circ}\right.$ to $\left.30^{\circ} \mathrm{C}\right)$ for about two weeks to three weeks. Finally, dry leaves and barks were pulverized using a grinder to obtain a fine powder, which was used for the preparation of total extracts aqueous ethanol and methanol.

Bacterial strains: The isolates included reference bacterial strains: (E. coli ATCC 25922, S. aureus ATCC 25923), clinical sensitive strains (S. aureus 079y/09, E. coli 766c/09 and K. pneumoniae 768c/09) and resistant strains (S. aureus $762 \mathrm{c} / 08, S$. aureus 908c/09, E. coli 066/08, E. coli 555/08, K. pneumoniae $485 / 08$, K. pneumoniae $773 \mathrm{c} / 09$ and one beta-lactam antibiotic) . These were provided by the collection of Laboratory of Virology \& Bacteriology of Institute Pasteur of Abidjan in Ivory Coast.

Preparation of plant extracts

Preparation of the aqueous extract total: This extraction was performed according to the method described by Ackah et al. (2008). Hundred grams (100 g) powder plant were stirred vigorously in 2 liters of distilled water using an electric mixer. The mixture was filtered twice through cotton wool, then through Whatman filter paper ( $N$-1). The filtrate was evaporated to dryness using under vacuum in a rotary evaporator (Buchi) at $60^{\circ} \mathrm{C}$ to obtain a powder. more than $80 \%$ of the population in Africa still use traditional medicine to satisfy their health needs. Among the most utilized plants is Terminalia catappa (Badamier, Cocoma) (Fofana, 2004), traditionally used for its antiparasitic, antiinfectious, anti diarrheal, anti hypertensive and anti diabetic property. It is also used in the treatment of asthma, skin diseases, gastrointestinal diseases, respiratory, cardiovascular and rheumatic diseases, scabies, leprosy, prurigo, sores, headache disorders, gonorrhea and leucorrhoea (Ackah et al., 2008; Sumitra and Nair, 2008, Annegowda et al., 2010;) Given the properties of this plant, our team wanted to study the validity of its antimicrobial qualities. Thus, we chose to test the antibacterial activity against ESBL producing and MRSA by extracts of bark and leaves of Terminalia catappa

Preparation of alcoholic extracts: Preparing ethanolic and methanolic extracts was made using the same method described above using the respective solvents ethanol and methanol. The filtrate is concentrated on a rotary evaporator under reduced pressure at $50^{\circ} \mathrm{C}$ and then dried in an oven at $40^{\circ} \mathrm{C}$.

Extracts obtained were stored in a refrigerator until used for bioassays.

Extract yield: The yield was calculated according to the formula:

$$
R(\%)=M_{1} \times 100 / M_{0}
$$

$R$ (\%): Extract yield; $M_{1}$ : extract quantity $(g) ; M_{0}$ : powder quantity of leaves or barks of $T$. catappa used by extraction (g). (Bssaibis, 2009)

Phytochemical analysis: The freshly prepared extracts were subjected to standard phytochemical analyses to test for the presence of the phytoconstituents Alkaloids, Saponins, Tannins, terpènoïdes, flavonoid, coumarin and substances quinoniques (Adebayo-Tayo et Adegoke, 2008, Babayi, 2004).

Confirmatory test for ESBL-producing $K$. pneumoniae and $E$. coli isolates: Antimicrobial susceptibility of Gram-negative clinical strains was determined by standard antibiogramme, according to the manufacturer's recommendation (CASFM, 2009). Confirmatory test for MRSA: Susceptibility to methicillin was determined by the method of KirbyBauer diffusion according to recommendations of the susceptibility of the French Society of Microbiology (CASFM, 2009). The antibiotic was tested cefoxitin (30 


\section{Mbengui et al J. Appl. Biosci. 2013. Comparative study on antibacterial activity of Terminalia- catappa on Multiresistant strains}

$\mu \mathrm{g})$. The quality control was performed with reference strains E. coli ATCC 25922 and S. aureus ATCC 25925.

Paper disc agar diffusion method: Antibacterial activity of the aqueous and organic extracts of Terminalia catappa leaves and bark extracts sample was evaluated by the paper disc diffusion method described by Doughari et al., (2007); Adebayo-Tayo and Adegoke (2008). Mueller-Hinton medium (GMH) was used for culture of bacteria. For determination of antibacterial activity, bacterial cultures were adjusted to $0.5 \mathrm{McF}$ arland turbidity standard and inoculated onto GMH plates. Sterile filter paper discs (diameter $6 \mathrm{~mm}$ ) impregnated with $10 \mu \mathrm{l}$ of extract dilutions was reconstituted in minimum amount of solvent at concentration of $100 \mathrm{mg} / \mathrm{ml}$, and applied over each of the culture plates previously seeded with the 0.5 McFarland. Bacterial cultures were then incubated at $37^{\circ} \mathrm{C}$ for $24 \mathrm{~h}$. All the results were compared with the disc of standard antibacterial antibiotic ceftazidim (30 $\mu \mathrm{g})$ and cefoxitin $(30 \mu \mathrm{g})$ for Enterobacteriaceae (Escherichia coli and Klebsiella pneumoniae) and Staphylococcus aureus respectively. The antibacterial activity was evaluated by measuring the diameter of inhibition zone. The experiment was repeated thrice and the mean of the diameter of the inhibition zones was calculated.

Determination of minimal inhibitory concentration and minimal bactericidal concentration: The Minimal Inhibitory Concentration (MIC) and the Minimal

\section{RESULTS}

Extract efficiency: The total mass of plant material extracted by the different solvents (water, ethanol and methanol) from $100 \mathrm{~g}$ of plant material is presented in the Figure 1. Yields for the various extracts showed values between $11.87 \pm 0.13 \%$ and $19.75 \pm 0.17 \%$. Among the three solvents used, methanol gave the highest yields. On the organ used, the highest yields were obtained with bark.
Bactericidal Concentration (MBC) was determined according to Wilkinson and Gentry revised by N'guessan et al. 2007. MIC of the extracts of Terminalia catappa leaves and bark was estimated for each of the test organisms in triplicates. $1.8 \mathrm{ml}$ of Mueller-Hinton broth $(\mathrm{BMH})$ was added into $0.2 \mathrm{ml}$ of varying concentrations of the extracts $(100.0 ; 50.0 ; 25.0 ; 12.50$; $6.25 ; 3.125 ; 1.56 ; 0.78 ; 0.39$ and $0.0195 \mathrm{mg} / \mathrm{ml})$. Then, a loopful of the test organism previously diluted to 0.5 McFarland turbidity standard was introduced to the tubes. A tube containing nutrient broth only was seeded with the test organisms as described above to serve as control. Tubes containing bacterial cultures were then incubated at $37^{\circ} \mathrm{C}$ for $24 \mathrm{~h}$. After incubation, the tubes were then examined for microbial growth by observing for turbidity. To determine MBC, a loopful of broth was collected from tubes, which did not show any growth and inoculated on sterile Mueller-Hinton agar (GMH) by streaking. Nutrient agar (GMH) only were streaked with the test organisms respectively to serve as control. Plates inoculated with bacteria were then incubated at $37^{\circ} \mathrm{C}$ for 24 hours. After incubation, the concentration at which no visible growth was seen was noted as the minimum bactericidal concentration.

Statistical analysis: Experiments were conducted in triplicate. Data were analyzed by one-way ANOVA followed by Dennett's t-test using Instat $₫$ (Graph Pad software, U.S.A). At $95 \%$ confidence interval $p<0.05$ was considered statistically significant.

Phytochemical analysis: The result of the phytochemical analysis show that the Methanolic, Ethanolic and Aqueous of leaf and bark extracts of $T$. catappa are rich in Flavonoids, Alkaloid, Steroid and Terpenoids, gallic Tannins, Saponins and Coumarins with the exception of the aqueous extract (Figure 2). The presence of these constituents has been reported to account for the exertion of antimicrobial activity by plant. 
Yield (\%)

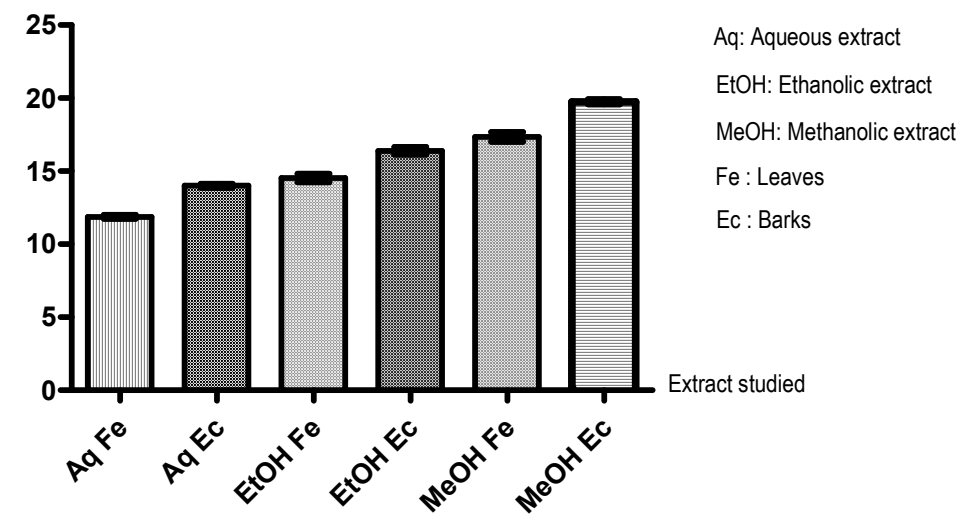

Figure 1: Yield of $T$. catappa extracts

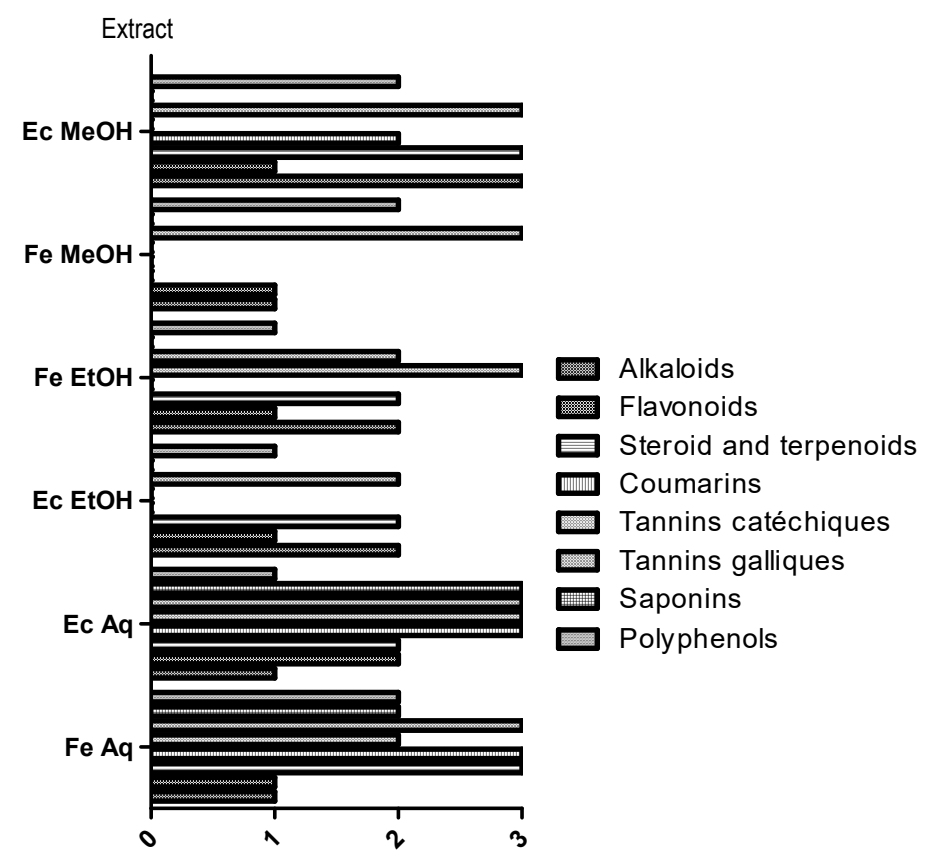

Figure 2: Screening Phytochemical of the extracts of the leaves and barks of T. catappa

Antibacterial activity of the crude extracts: All the extracts tested showed antibacterial activity against at least one of the bacterial strains tested with inhibition zones ranging from 0 to $15.4 \pm 0.30 \mathrm{~mm}$. One noticed that the susceptibility of the bacteria to the crude extracts of the leaf and bark of $T$. catappa based on inhibition zone diameters varied according to the microorganism, the results are reported in Table 1. In assays disk diffusion, extracts tested showed variable degrees of antimicrobial activities against the tested organisms. The best activity $(8.67 \pm 0.33$ to $15.4 \pm 0.30$ $\mathrm{mm}$ ) has been demonstrated by the methanolic extract of bark, and least, by aqueous extract of leaf ( 0 to $10.00 \pm 0.58 \mathrm{~mm}$ ) Table 1 . An inhibition zone diameter $(\geq 11 \mathrm{~mm}$ ) was chosen as a break-point of bacterial susceptibility of the extracts and the antibiotic.
Ceftazidime $(30 \mu \mathrm{g})$ and cefoxitin $(30 \mu \mathrm{g})$ were used as positive control and had a diameter of inhibition zone of $13.33 \pm 0.88$ to $30.67 \pm 0.67 \mathrm{~mm}$. It was important to note that the methanolic extract was active against the Gram-positive and all Gram-negative bacteria used in this study at the lowest concentration tested and the pattern of activity observed was such that the zone diameter of inhibition for each organism was directly proportional to the concentration of the extract used. The Gram-positive bacteria ( $S$. aureus) were the most sensitive while the Gram-negative bacteria (especially Klebsiella pneumoniae) were more resistant. The bark extracts generally showed a better activity against the test organisms compared to the leaf extracts. The difference is significant $(P<0.0001)$. 
Mbengui et al J. Appl. Biosci. 2013. Comparative study on antibacterial activity of Terminaliacatappa on Multiresistant strains

Minimum inhibition concentration (MIC) and minimum bactericidal concentration (MBC)

$\mathrm{MIC}$ and MBC values were ranged from 0.52 to 41.67 $\mathrm{mg} / \mathrm{ml}$ and 1.56 to $>100 \mathrm{mg} / \mathrm{ml}$ respectively. The bactericidal and bacteriostatic effect of the extracts was determined using the ratio MBC/MIC (Table 2 and Table 3). The result showed that Klebsiella pneumoniae had the highest MIC $(41.67 \mathrm{mg} / \mathrm{ml})$ and MBC (> 100 $\mathrm{mg} / \mathrm{ml}$ ) with the aqueous extract of leaf, while the lowest MIC of $1.56 \mathrm{mg} / \mathrm{ml}$ was shown by Staphylococcus aureus with the methanolic extract of bark. The MIC and MBC values were generally lower for the bark extracts against the test organisms compared to those of the leaf extracts. 
Table 1: Zone of inhibition $(\mathrm{mm})$ of the extracts of the leaf of $T$. catappa and céfoxitine and ceftazidime against $E$. coli, K. pneumoniae and S. aureus

\begin{tabular}{c|c|c|c|c|c|c|c}
\hline \multirow{2}{*}{ Eacterial strain } & \multicolumn{3}{|c|}{ Leaves $(\mathbf{1 0 0} \mathrm{mg} / \mathrm{ml})$} & \multicolumn{3}{c|}{ Barks (100 mg/ml) } & \multicolumn{1}{c|}{ Caz/Fox } \\
\cline { 2 - 7 } & Aqueous & Ethanol & Methanol & Aqueous & Ethanol & Methanol & \\
\hline E. coli & $6.67 \pm 0.33$ & $8.67 \pm 0.33$ & $10.67 \pm 0.67$ & $10.67 \pm 0.17$ & $11.67 \pm 0.17$ & $13.67 \pm 0.33$ & $30.00 \pm 0.58$ \\
E. coli BLSE & $5.67 \pm 0.33$ & $7.33 \pm 0.33$ & $9.33 \pm 0.33$ & $9.17 \pm 0.17$ & $10.83 \pm 0.44$ & $12.17 \pm 0.17$ & $14.33 \pm 0.33$ \\
E. coli ATCC & $6.83 \pm 0.17$ & $9.67 \pm 0.33$ & $11.00 \pm 0.58$ & $10.83 \pm 0.17$ & $11.67 \pm 0.33$ & $13.33 \pm 0.33$ & $31.67 \pm 0.33$ \\
K. pneumoniae & $5.17 \pm 0.17$ & $7.00 \pm 0.58$ & $9.67 \pm 0.88$ & $8.83 \pm 0.17$ & $10.33 \pm 0.33$ & $12.33 \pm 0.33$ & $26.33 \pm 0.33$ \\
K. pneumoniae BLSE & - & $6.33 \pm 0.33$ & $8.67 \pm 0.33$ & $6.50 \pm 0.29$ & $8.67 \pm 0.17$ & $10.83 \pm 0.17$ & $13.33 \pm 0.88$ \\
SASM & $9.83 \pm 0.17$ & $11.67 \pm 0.33$ & $13.67 \pm 0.33$ & $11.33 \pm 0.33$ & $13.17 \pm 0.17$ & $15.33 \pm 0.33$ & $30.67 \pm 0.67$ \\
SARM & $7.33 \pm 0.33$ & $10.67 \pm 0.33$ & $12.83 \pm 0.17$ & $9.83 \pm 0.17$ & $11.67 \pm 0.33$ & $13.33 \pm 0.33$ & $25.67 \pm 0.88$ \\
S. aureus ATCC & $10.00 \pm 0.58$ & $11.00 \pm 0.58$ & $13.33 \pm 0.88$ & $11.50 \pm 0.29$ & $13.25 \pm 0.25$ & $15.4 \pm 0.30$ & $30.17 \pm 0.44$ \\
\hline
\end{tabular}

Table 2: Minimum inhibitory concentration (MIC) and minimum bactericidal concentration (MBC) of the leaf of $T$. catappa

\begin{tabular}{|c|c|c|c|c|c|c|c|c|c|c|c|c|}
\hline \multirow{2}{*}{$\begin{array}{l}\text { Bacterial } \\
\text { strain }\end{array}$} & \multicolumn{4}{|c|}{ Aqueous } & \multicolumn{4}{|c|}{ Ethanol } & \multicolumn{4}{|c|}{ Methanol } \\
\hline & CMI & CMB & $\begin{array}{l}\text { CMB } \\
\text { /CMI }\end{array}$ & $\begin{array}{c}\text { Antibacterial } \\
\text { activity }\end{array}$ & CMI & CMB & $\mathrm{CMB} / \mathrm{CMI}$ & $\begin{array}{l}\text { Antibacterial } \\
\text { activity }\end{array}$ & CMI & CMB & $\mathrm{CMB} / \mathrm{CMI}$ & $\begin{array}{l}\text { Antibacterial } \\
\text { activity }\end{array}$ \\
\hline E. coli & $\begin{array}{r}10.42 \\
\pm 2.08\end{array}$ & $\begin{array}{l}41.67 \\
\pm 8.33\end{array}$ & 4 & Bactericidal & $\begin{array}{c}8.33 \pm \\
2.08\end{array}$ & 25.00 & 3 & Bactericidal & 3.12 & $\begin{array}{c}8.33 \pm \\
2.08\end{array}$ & 2.67 & Bactericidal \\
\hline E. coli BLSE & $\begin{array}{l}20.83 \\
\pm 4,17\end{array}$ & 50.00 & 2.4 & Bactericidal & 12.50 & $\begin{array}{l}41.67 \\
\pm 8.33\end{array}$ & 3.33 & Bactericidal & 3.12 & 6.25 & 2 & Bactericidal \\
\hline E. coli ATCC & $\begin{array}{l}10.42 \\
\pm 2.08\end{array}$ & $\begin{array}{l}41.67 \\
\pm 8.33\end{array}$ & 4 & Bactericidal & $\begin{array}{c}5.21 \pm \\
1.04\end{array}$ & 25.00 & 4.79 & Bacteriostatic & 12.50 & 12.50 & 1 & Bactericidal \\
\hline $\begin{array}{l}\text { K. } \\
\text { pneumoniae }\end{array}$ & 12.50 & 50.00 & 4 & Bactericidal & $\begin{array}{r}16.67 \\
\pm 4.17\end{array}$ & $\begin{array}{l}41.67 \\
\pm 8.33\end{array}$ & 2.50 & Bactericidal & $\begin{array}{r}10.42 \\
\pm 2.08\end{array}$ & 12.50 & 1.20 & Bactericidal \\
\hline & 41.67 & $>100$ & - & Bacteriostatic & 25.00 & 100 & 4 & Bactericidal & 12.50 & 41.67 & 3.33 & Bactericidal \\
\hline $\begin{array}{l}\text { pneumoniae } \\
B L S E\end{array}$ & \pm 8.33 & & & & & & & & & \pm 8.33 & & \\
\hline SASM & $\begin{array}{c}4.16 \pm \\
1.04\end{array}$ & $\begin{array}{c}8.33 \pm \\
2.08\end{array}$ & 2 & Bactericidal & $\begin{array}{c}4.16 \pm \\
1.04\end{array}$ & 6.25 & 1.50 & Bactericidal & 1.56 & 1.56 & 1 & Bactericidal \\
\hline SARM & 6.25 & 12.50 & 2 & Bactericidal & 6.25 & 12.50 & 2 & Bactericidal & $\begin{array}{c}4.16 \pm \\
1.04\end{array}$ & 6.25 & 1.50 & Bactericidal \\
\hline $\begin{array}{l}\text { S. aureus } \\
\text { ATCC }\end{array}$ & $\begin{array}{c}4.16 \pm \\
1.04\end{array}$ & 6.25 & 1.50 & Bactericidal & 3.12 & $\begin{array}{c}4.16 \pm \\
1.04\end{array}$ & 1.33 & Bactericidal & 1.56 & 1.56 & 1 & Bactericidal \\
\hline
\end{tabular}


Table 3: Minimum inhibitory concentration (MIC) and minimum bactericidal concentration (MBC) of the bark of $T$. catappa

\begin{tabular}{|c|c|c|c|c|c|c|c|c|c|c|c|c|}
\hline \multirow{2}{*}{$\begin{array}{l}\text { Bacterial } \\
\text { strain }\end{array}$} & \multicolumn{4}{|c|}{ Aqueous } & \multicolumn{4}{|c|}{ Ethanol } & \multicolumn{4}{|c|}{ Methanol } \\
\hline & CMI & CMB & $\mathrm{CMB} / \mathrm{CMI}$ & $\begin{array}{c}\text { Antibacterial } \\
\text { activity }\end{array}$ & CMI & CMB & CMB/CMI & $\begin{array}{c}\text { Antibacterial } \\
\text { activity }\end{array}$ & $\mathrm{CMI}$ & CMB & $\mathrm{CMB} / \mathrm{CMI}$ & $\begin{array}{c}\text { Antibacterial } \\
\text { activity }\end{array}$ \\
\hline E. coli & 6.25 & $\begin{array}{c}20.83 \pm \\
4.17\end{array}$ & 3.33 & Bactericidal & $\begin{array}{c}4.16 \pm \\
1.04\end{array}$ & 12.50 & 3 & Bactericidal & $\begin{array}{c}1.30 \pm \\
0.26\end{array}$ & 3.12 & 2.40 & Bactericidal \\
\hline E. coli BLSE & 12.50 & $\begin{array}{c}20.83 \pm \\
4.17\end{array}$ & 1.67 & Bactericidal & $\begin{array}{c}8.33 \pm \\
2.08\end{array}$ & 12.50 & 1.50 & Bactericidal & $\begin{array}{c}4.16 \pm \\
1.04\end{array}$ & 12.50 & 3 & Bactericidal \\
\hline E. coli ATCC & 6.25 & $\begin{array}{c}20.83 \pm \\
4.17\end{array}$ & 3.33 & Bactericidal & 3.12 & 12.50 & 4 & Bactericidal & 1.56 & 3.12 & 2 & Bactericidal \\
\hline K. pneumoniae & 12.50 & $\begin{array}{c}41.67 \pm \\
8.33\end{array}$ & 3.33 & Bactericidal & 6.25 & 12.50 & 2 & Bactericidal & $\begin{array}{c}4.16 \pm \\
1.04\end{array}$ & $\begin{array}{c}5.21 \pm \\
1.04\end{array}$ & 1.25 & Bactericidal \\
\hline $\begin{array}{l}\text { K. pneumoniae } \\
\text { BLSE }\end{array}$ & 25.00 & $>100$ & - & Bacteriostatic & 12.50 & $\begin{array}{c}20.83 \pm \\
4.17\end{array}$ & 1.67 & Bactericidal & 6.25 & $\begin{array}{c}10.42 \pm \\
2.08\end{array}$ & 1.67 & Bactericidal \\
\hline SASM & 3.12 & $\begin{array}{c}10.42 \pm \\
2.08\end{array}$ & 3.33 & Bactericidal & $\begin{array}{c}2.08 \pm \\
0.52\end{array}$ & 3.12 & 1.50 & Bactericidal & $\begin{array}{c}0.52 \pm \\
0.13\end{array}$ & 1.56 & 3 & Bactericidal \\
\hline SARM & $\begin{array}{c}8.33 \pm \\
2.08\end{array}$ & $\begin{array}{c}16.67 \pm \\
4.17\end{array}$ & 2 & Bactericidal & 3.12 & 12.50 & 4 & Bactericidal & $\begin{array}{c}1.30 \pm \\
0.26\end{array}$ & $\begin{array}{c}4.16 \pm \\
1.04\end{array}$ & 3.20 & Bactericidal \\
\hline $\begin{array}{l}\text { S. aureus } \\
\text { ATCC }\end{array}$ & 3.12 & 12.50 & 4 & Bactericidal & $\begin{array}{c}2.08 \pm \\
0.52\end{array}$ & 3.12 & 1.50 & Bactericidal & 0.78 & 1.56 & 2 & Bactericidal \\
\hline
\end{tabular}




\section{DISCUSSION}

The development of drug resistance in human pathogens against commonly used antibiotics has necessitated a search for new antimicrobial substances. Higher plants produce diverse secondary metabolites with different biological activities. These natural compounds may be a source of compounds with antimicrobial effects and therefore possible candidates for the development of new antibacterial agents (Adefuye et al., 2007, Lagnika et al., 2012). In our study, aqueous, ethanol, and methanol extracts of leaves and bark of $T$. catappa were tested for the presence of antimicrobial activity against 11-gram positive and gram-negative bacteria implicated in infectious diseases. The majority of traditional healers use water to extract active compounds from this plant, because water is not harmful to humans and is generally cheap and easily acquired. However, successful isolation of compounds from plant material is largely dependent on the type of solvent used in the extraction process (Masoko et al., 2008). Use of water alone leads to difficulties in isolating non-polar active compounds. The current study, observed that methanol and ethanol were good solvents for extraction with yield of $19.75 \pm 0.17 \%$ and $16.39 \pm 0.26 \%$ respectively while water was the least $11.87 \pm 0.13 \%$. The barks and the methanolic extract have given better yield. The results correspond to those of Ackah et al (2008) and Masoko et al (2008) which have respectively shown agreat concentration of the active principals with the methanol. That justifies the fact that the methanolic extract of the barks presented a better activity than most of the tested strains. $(P<0.0001) S$. aureus was the most sensitive strain and Klebsiella pneumoniae ESBL was not the least sensitive strain. For an extract considered, comparatively to the control inoculum there

\section{CONCLUSION}

This study has allowed us to bring out the antibacterial activity of Terminalia catappa and to compare the antibacterial potential of the barks and the leaves of this plant against the multiresistant bacterial strains. Comparatively, barks have shown a good activity than leaves and the methanolic extract of barks has shown better activity with a bactericidal effect upon all the tested strains. This activity was dose dependent. The was a progressive decrease in the thickness of the layer of colonies on the streak but also a decrease in the number of colonies from low concentrations to high concentrations; thus reflecting a dose-dependent sensitivity. These results have showed also that all extracts were bactericidal for all the tested strains (MBC/MIC $\leq 4$, Marmonier, 1990). It appears from the analysis of results, that the most bactericidal extract was the methanolic extract of barks with a MBC of 1.56 $\mathrm{mg} / \mathrm{ml}$ while the least bactericidal extract was aqueous extract of leaves because of its higher value of MBC (> $100 \mathrm{mg} / \mathrm{ml}$ ). Moreover, some settled report established on the basis of the minimal bactericidal concentration confirm that the barks are better in activity than the leaves, on the other hand the methanolic extract is more active than the ethanolic extract and itself more active than the aqueous extract. Similar results were also shown by Pawar and Pal, 2002; Babayi et al., 2004, Nair Sumitra and Chanda, 2008; and Manzur et al, 2011). Moreover, the Gram-positive bacteria were more susceptible than Gram-negative bacteria. This is in agreement with previous reports that plant extracts are more active against Gram-positive bacteria than Gram-negative bacteria (Prashanth Kumar et al, 2006). The extracts of the barks and leaves of $T$. catappa studied were found to contain more of the following phytochemical compounds flavonoids, Alkaloids, steroid and terpenoids, Gallic, tannis, saponins and couramins with variable concentration according to the organ and extract. The antibacterial activity of this medicinal plant may therefore be due to the presence of flavonoids, tannis, saponins, steroid and terpenoids (Babayi et al., 2004, Fofana, 2004, Ackah et al, 2008) and hence, the use of this plant in the anti-infectious and anti-diarrhea treatment.

bark of this plant may provide novel or lead compounds, which could become starting materials for the synthesis of new drugs. Therefore, further studies to isolate and characterize the active compounds are essential. This study thus can also justify the traditional use of Terminalia catappa in the treatment of many diseases.

\section{ACKNOWLEDGEMENTS}

The authors are thankful to the Institute Pasteur of Côte d'Ivoire (IPCI) and Biochemical Pharmcodynamie Laboratory of Felix Houphouet Boigny University 
RÉFÉRENCES BIBLIOGRAPHIQUES :

ACKAH JAAB, KRA AKM, ZIRIHI GN et GUEDEGUINA F (2008). Évaluation et essais d'optimisations de l'activité anticandidosique de Terminalia Catappa linn (tekam3), un extrait de combretaceae de la pharmacopée ivoirienne. Bulletin de la Société Royale des Sciences de Liège, Vol. 77, pp. 120 - 136

Adebayo-Tayo BC and Adegoke AA (2008). Phytochemical and microbial screening of herbal remedies in Akwa Ibom State, South Southern Nigeria. Journal of Medicinal Plants Research Vol. 2(11): 306-310

Adefuye A. O., Samie A. and Ndip R. N. (2011). In-vitro evaluation of the antimicrobial activity of extracts of Bridelia micrantha on selected bacterial pathogens. Journal of Medicinal Plants Research Vol. 5(20), pp. 5116-5122.

Annegowda HV, Anwar LN, Mordi MN, Ramanathan S, Mansor SM (2010). Influence of sonication on the phenolic content and antioxidant activity of Terminalia catappa L. leaves. Pharmacognosy Res. 2(6): 368-373.

Babayi H, Kolo I, Okogun JI, ljah UJJ (2004). The antimicrobial activities of methanolic extracts of Eucalyptus camaldulensis and Terminalia catappa against some pathogenic microorganisms Biokemistri 16(2):106-111.

Bssaibis F, Gmira N, Meziane M (2009) Activité antibactérienne de Dittrichia viscosa (L.) W. Greuter. Rev. Microbiol. Ind. San et Environn. Vol 3, N¹, p : 44-55

Belmonte O, Drouet D, Alba J, Moiton MP, Kuli B, Lugagne-Delpon N, Mourlan $C$ and JaffarBandjee MC (2010) Evolution de la résistance des enterobacteries aux antibiotiques sur l'île de la Reunion : émergence des bêta-lactamases à spectre élargi. Pathologie Biologie 58 (2010)18 - 24.

CASFM (2009). Recommandations 2009. Edition de Janvier 2009. 50p.

Doughari JH, Pukuma MS, De N (2007). Antibacterial effects of Balanites aegyptiaca L. Drel. and Moringa oleifera Lam. on Salmonella typhi, African Journal of biotechnology, 6 (19): 2212 $-2215$.

Fofana S (2004) Exploration biochimique sur le pouvoir immunogène de trois plantes en Côte d'Ivoire : Alstonia boonei (apocynaceae), Mitragyna ciliata (rubiaceae) et Terminalia Catappa (combretaceae). Thèse de Docteur en Pharmacie. FMPO, Université de Bamako.123P.

Gandolfi I, Franzetti A, Bertolini V, Gaspari E, Bestetti $G$ (2011). Antibiotic resistance in bacteria associated with coarse atmospheric particulate matter in an urban area Journal of Applied Microbiology 110: 1612-1620

Guessennd KN (2005). Détermination de l'activité antibactérienne des substances naturelles issues des plantes de la pharmacopée de Côte d'ivoire. Fiche technique $n^{\circ} 2, \mathrm{IPCl} 18 \mathrm{p}$.

Kacou-N'douba A, Koffi KS, Ekaza E, Kouamé EC, Anne BJC, Dosso M (2011). Staphylococcus Aureus Infection and Virulence Genes in Abidjan (Côte d'Ivoire). European Journal of Scientific Research Vol.52 № 3 : 339-344

Lagnika L., Amoussa M., Adjovi Y. and Sanni A. (2012): Antifungal, antibacterial and antioxidant properties of Adansonia digitata and Vitex doniana from Bénin pharmacopeia. Journal of Pharmacognosy and Phytotherapy Vol. 4(4), pp. 44-52.

Maghrani M, Zeggwagh N, Michel J, Eddoules M (2005). Antihypertensive effect of Lepidium sativum $L$. in spontaeneously hypertension rats, Journal of Ethnopharmacology, 100(102): 193 - 197.

Manzur A, Raju A, Rahman S (2011). Antimicrobial Activity of Terminalia catappa Extracts against Some Pathogenic Microbial Strains. Pharmacology \& Pharmacy, 2, 299-305.

Marmonier, A. A (1990). Introduction aux techniques d'étude des antibiotiques.

Bactériologie Médicale, technique usuelles.227 - 236.

Masoko P, Mmushi TJ, Mogashoa MM, Mokgotho MP, Mampuru LJ, Howard RL (2008). In vitro evaluation of the antifungal activity of Sclerocarya birrea extracts against pathogenic yeasts. Afr. J. Biotechnol., 7(20) : 3521-3526.

Nair R and Sumitra C (2008). Antimicrobial Activity of Terminalia catappa, Manilkara zapota and Piper betel Leaf Extract. Indian J Pharm Sci.May-Jun ; 70(3) : 390-393.

Ndiaye AOK (2005). Les Enterobacteries secretrices de beta-lactamases à spectre élargi. Thèse de Docteur en Pharmacie. Univ. Cheikh Anta Diop de Dakar. 69p.

N'guessan JD, Dinzedi MR, Guessennd N, Coulibaly A, Dosso M, Djaman AJ, Guede-Guina F (2007). Antibacterial activity of the aqueous extract of Thonningia sanguinea against ExtendedSpectrum- $\beta$ - Lactamases (ESBL) producing Escherichia coli and Klebsiella pneumoniae strains. Tropical Journal of Pharmaceutical Research, September; 6 (3): 779-783

Nyenje M and Ndip RN (2011). In-vitro antimicrobial activity of crude acetone extract of the stem bark of Combretum molle against selected 
bacterial pathogens. Journal of Medicinal Plants Research Vol. 5(21), pp. 5315-5320.

Organisation Mondiale de la Santé (WHO) (2002 a). Résistance aux antimicrobiens. Aide-mémoire Nº194 Révisé 6P.

Organisation Mondiale de la Santé (OMS) (2002 b). Stratégie de l'OMS pour la médecine traditionnelle pour 2002-2005. WHO/EDM/TRM/2002, Genève, $65 \mathrm{p}$.

Pawar SP, Pal SC (2002). Antimicrobial activity of extracts of Terminalia catappa root. Indian J Med Sci, 56:276-8.

Prashanth Kumar V, Neelam SC, Padh H and Rajni M (2006). Search for Antibacterial and Antifungal Agents from Selected Indian Medicinal Plants. Journal of Ethnopharmacology, Vol. 107, № 2, pp. 182-188.

Rong-Dih L, Yi-Ping C, Mei-Hsien L (2005). Antimicrobial Activity of Antibiotics in Combination with Natural Flavonoids against
Clinical Extended-Spectrum $\beta$-Lactamase (ESBL)-producing Klebsiella pneumoniae. Phytother. Res. 19: 612-617

Sorlózano A, Gutiérrez J, Romero JM, de Dios Luna J, Damas M and Piédrola G (2007) Activity in vitro of twelve antibiotics against clinical isolates of extended-spectrum betalactamase producing Escherichia coli. Journal of Basic Microbiology 2007, 47, 413-416.

Soro D, Kone MW, Kamanzi K (2010). Evaluation des activités antimicrobiennes et anti-radicaux libres de quelques taxons bioactifs de Côte d'Ivoire. European Journal of Scientific Research Vol.40 No.2, pp.307-317

Stahl JP (2006). Épidémiologie, contrôle et traitements des résistances aux antibiotiques : compterendu du $45^{\mathrm{e}}$ congrès ICAAC, Washington 2005. 